\title{
CORTISONE AND ITS ANALOGUES IN HAEMATOLOGY
}

\author{
By S. M. Lewis, B.Sc., M.B., Ch.B., D.Clin.Path. \\ Dept. of Haematology, Postgraduate Medical School of London
}

The influence of adrenal cortical secretion on blood elements was first noted in mice by Dougherty and White (1943) who showed that a single injection of pituitary adrenotrophic hormone produced an absolute lymphopenia with a relative and absolute neutrophilia, and an increase in the numbers of erythrocytes and haemoglobin content.

Hills, Forsham and Finch (1948) demonstrated the influence of ACTH on circulating leucocytes in man. Thorn et al. (1948) showed the relationship between leucocyte numbers and adrenal activity, and Hench et al. (1949) in the first clinical trial of Compound $\mathrm{E}$ (or cortisone) on patients with rheumatoid arthritis, reported a concomitant increase in haemoglobin content and erythrocyte count during the course of therapy. It was apparent that there was good rationale for the use of cortisone and ACTH in blood diseases, and Farber et al. (1950) recorded a good response to ACTH in a five-year-old child with acute leukaemia. Results of subsequent applications were reviewed by Wintrobe et al. (I95I).

Several analogues of cortisone are now available. Their relative potencies and advantages are described elsewhere in this Journal. In the haematological disorders to be discussed, cortisone or any of the related products in an equivalent dose, can, as a rule, be used with equal effectiveness.

The effects of adrenocorticosteroids on haemopoietic function occur by several possible mechanisms which are not fully understood.

\section{Possible Mechanism of Effects Eosinopenia:}

Inhibition of production or release of eosinophils from the bone marrow.

Sequestration of eosinophils in spleen and/or lung.

Destruction of eosinophils in peripheral blood.

\section{Erythropoiesis, Granulopoiesis:}

Bone marrow stimulus.
Lymphopenia:

Involution of lymphoid tissue. This occurs of fixed lymphoid tissue of thymus and lym nodes (in which the germ centres may disappear) and also in the peripheral bloot. There is a similar, though temporary, effeget on the lymphoid cells of lymphosarcoma aed chronic lymphatic leukaemia.

\section{Depression of Antibody Production:}

Secondary to involution of lymphoid tissue.

Control of Hypersplenism:

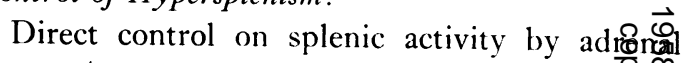
cortex.

Therapeutic trials with cortisone and its rivatives and ACTH on haematological disordēs have met with varying degrees of success. some groups of conditions steroids are firmpy established as the treatment of choice, either alo $\overrightarrow{g e}$ or in combination with other methods of treament, and this article reviews current thoughts the subject.

\section{Idiopathic Thrombocytopenic Purpura}

Steroids act both by improving capillary sistance and by increasing platelet response. Thes actions are unrelated, and there may be a satsfactory vascular response without any change in the thrombocytopenia. The vascular response occurs within 2 to 10 days, preceding the plateft response, which usually occurs on the 6th to I I day. Response to steroid is less satisfactory in the chronic phase than in the acute phase, with little rise in platelets, although there may be a sat factory vascular response, indicated by a nornfial capillary fragility test, normal bleeding time, ard remission of bleeding. Thus, even if the effectass temporary, steroids are of value in controlligh bleeding, in order to tide over the patient until there is spontaneous remission, or until splenectonomy can be carried out unhurriedly as elective procedure with minimal blood loss. 
may also be of value in postsplenectomy cases, when the operation has failed to control the bleeding, or has produced an incomplete remission. There is no evidence that steroid therapy has any adverse effect on the response to subsequent splenectomy nor on wound healing. Failure to respond to the hormones is no gauge of the effect of splenectomy.

Davidson et al. (1952), in an investigation of I4 patients, found that with steroids alone only three were cured and a further three obtained temporary relief. Robson (1954), however, reviewed 103 cases from his own and other series, and found that in two-thirds of the cases not subjected to splenectomy, hormonal treatment controlled or diminished haemorrhagic manifestations.

Thus, the treatment of choice should be:

\section{Acute ITP (Less than three months' duration):}

Initial dose of 150 units of ACTH or 150 to 300 $\mathrm{mg}$. of cortisone daily, reducing the dose after remission to the smaliest dose which maintains remission. Response is judged by decreasing capillary fragility and increasing platelet counts. If there has been platelet response, treatment should be continued for several months, but there is no point in continuing treatment beyond ten days if the patient fails to respond.

\section{Chronic ITP:}

Pre-operatively, 25 to 75 units $\mathrm{ACTH}$, or 75 to $250 \mathrm{mg}$. cortisone daily for three days prior to surgery, tapering off this treatment in three subsequent days.

\section{Secondary Thrombocytopenia}

In this mixed group, the thrombocytopenia which occurs in relation to hypersplenism benefits from steroid treatment, which should be given in dosages of the same order as in acute idiopathic thrombocytopenic purpura.

Drug-induced thrombocytopenia was reported to respond favourably to high doses of steroids in the 2 nd report of the M.R.C. Panel (1953). However, Thompson et al. (1954) reported no response to ACTH in two cases of thrombocytopenia secondary to gold therapy.

\section{Throinbotic Thrombocytopenic Purpura}

The histological appearance in this uncommon condition suggest a relationship to the collagen group of diseases. The use of steroids has been repor ted by Meacham et al. (195I) who induced a transient remission in one case, but Gendel et al. (1952), Adelson et al. (1954) and Marey et al. (1956) have reported cases who have failed to respond to large doses of cortisone and ACTH.

\section{Capillary Defects}

Early reports of the results of steroid therapy in Henoch-Schonlein disease were disappointing and in their 3 rd report the M.R.C. Panel (1955) found that of eight cases classified broadly as nonthrombocytopenic purpura, six failed to respond to adequate doses of ACTH over a period of 12 to 20 days. Wald and Kissin (1955) found that in a patient in whom hereditary purpura simplex and Henoch-Schonlein syndrome co-existed, treatment with a combination of $\mathrm{ACTH}$ and antihistamines produced a good response. Nabarro et al. (1955) treated a patient successfully with prednisone; Stefanini and Martino (1956) reported that prednisone was especially effective in the management of acute anaphylactoid purpura and 'vascular pseudohaemophilia,' Cohen (1957) reported that in a patient with severe HenochSchonlein purpura cortisone in a daily dose of $200 \mathrm{mg}$. failed to have any effect whereas $40 \mathrm{mg}$. of prednisolone daily produced a dramatic remission and this was maintained with a daily dose of $15 \mathrm{mg}$.

\section{Coagulation Mechanism}

Cosgriff et al. (1950) and later Godlowski (1951) reported that cortisone caused a decrease in coagulation time. Eisenmenger et al. (1952) studying this phenomenon in a series of patients with cirrhosis found no alteration in prothrombin, antithrombin, fibrinogen or platelet activity. The coagulation time decrease appears to be due to an antiheparin effect of the steroids. This has no therapeutic application in the control of coagulation defects but may be of significance in the production of thromboses. Eisenmenger records the development of portal thromboses in three of his patients with cirrhosis during treatment with ACTH. Patients on anticoagulant therapy and steroids may still develop thrombi despite apparent adequate anticoagulant dosage with a low level of blood 'prothrombin'; such patients should be controlled on heparin as well as by dicoumarol.

\section{Haemolytic Anaemias}

The introduction of cortisone and AC'TH has markedly influenced the management of acquired haemolytic anaemias due to auto-antibodies in a large proportion of which the haemolytic process can be interrupted and the anaemia relieved.

One of the actions of the steroids is the reduction of antibody concentrations in the serum but this is only one of several mechanisms of steroid action. Increased erythropoiesis, inhibition of erythrophagocytosis, prevention of antibody-antigen action by some blocking mechanism and inhibition of cell permeability play some part in the 


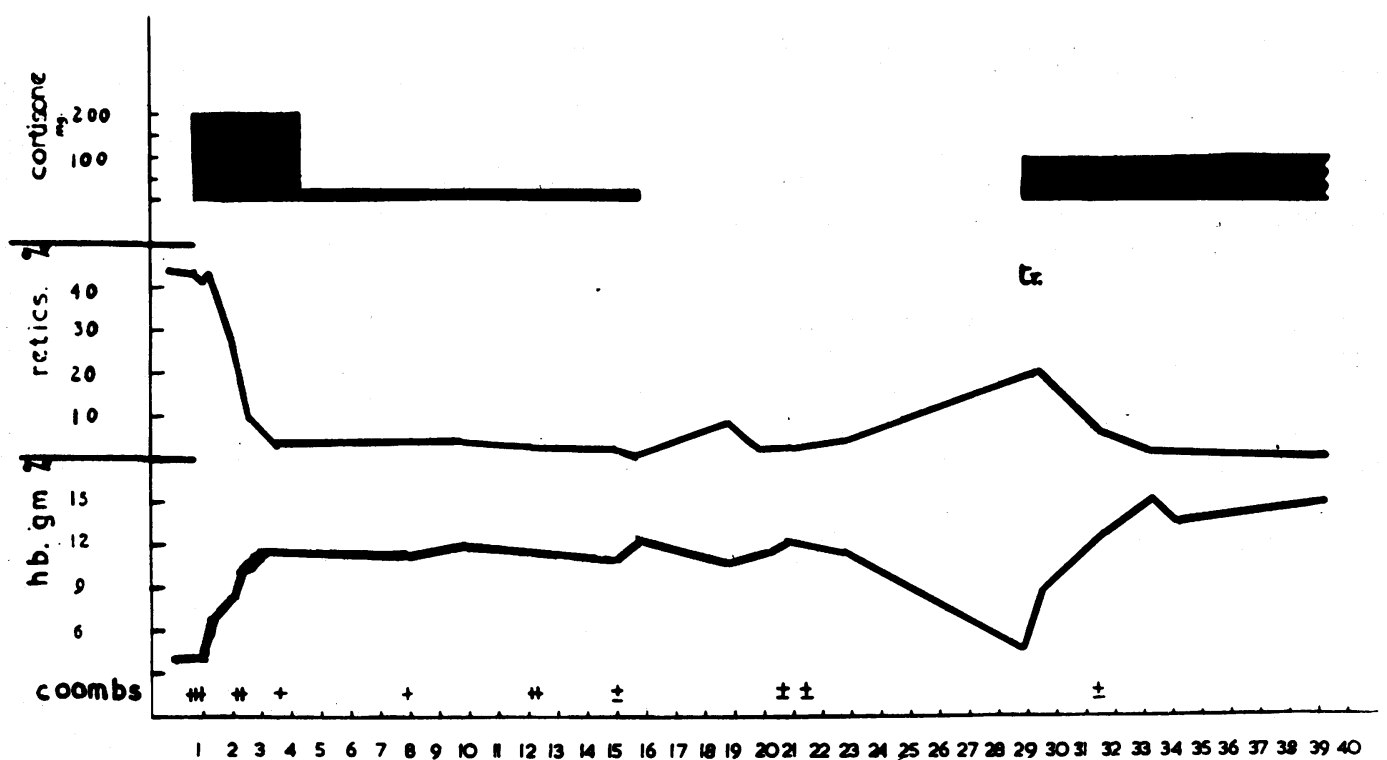

weeks

FIG. 1.-Acquired haemolytic anaemia (cold antibody type) in a ro-year-old child with disseminated lupus erythematosus. Haemolytic process well controlled by cortisone.

mechanism. In their second report the M.R.C. Panel (1953) recorded only moderate effectiveness in the treatment of acquired haemolytic anaemias, but as Dameshek (1952) pointed out, the doses had been low and in the third report of the M.R.C. Panel (1955) after doses of the steroids had been increased, there appeared to be excellent response, with only two out of ten patients failing to respond at all, while five patients went into complete remission.

Dacie (1954) reviewed the literature on the use of steroids in haemolytic anaemias, and recorded his findings in his own group of patients. Clinical and haematological remission (though without necessarily any alteration in antibody titre) were oberved in both idiopathic acquired haemolytic anaemia of the warm antibody and of the cold antibody type. In secondary haemolytic anaemia associated with auto-antibodies there may also be temporary haematological and clinical remission.

If the patients respond at all this will be shown within two weeks of the commencement of adequate treatment. Dosage required varies and it is emphasized that in an initial course treatment to the limit of the patient's tolerance may be necessary to control the haemolytic process. Starting with a daily dose of 300 to $400 \mathrm{mg}$. of cortisone, after response it is possible to cut down the dose to the minimal amount necessary to maintain the patient with a haemoglobin level of $10 \mathrm{gm}$. per cent. Impending relapse is indicated by a sliget fall in the erythrocyte count and haemoglober level, with a rising reticulocyte count (Fig. I Meyer and Ritz (1954) have suggested that as the adrenal may produce hormones other than cortisone which might be capable of supressing $\stackrel{\odot}{\propto}$ haemolytic activity, ACTH may be of value in in- $\overrightarrow{\vec{A}}$ ducing remission when cortisone alone has failed; 을 de Gruchy (1954) has found similar results in four patients. Conversely, patients may respond favourably to cortisone when ACTH had proved to be ineffective. Dameshek and Komninos (1956) have shown that on occasions prednisone has proved effective when cortisone has failed. Splenectomy is a well-recognised method of $\delta$ treatment of acquired haemolytic anaemia. Steroids may be used for as long a time as possible 윽 before splenectomy is recommended in order to give the steroid therapy adequate trial.

As Dameshek and Komninos point out, the failure of steroid therapy should not be accepted 0 until various preparations have been tried and if $\tilde{O}$ possible by' various routes of administration. It $\mathrm{N}$ is worth remembering that when there has been $O$ no response to an initial course of cortisone, and o splenectomy has failed to produce an adequate $\stackrel{\mathbb{D}}{\overparen{D}}$ response, a further course of cortisone, after $\stackrel{\infty}{+}$ splenectomy, may produce a satisfactory remission.

In haemolytic disease of the newborn steroids therapy to the mother during pregnancy does not 


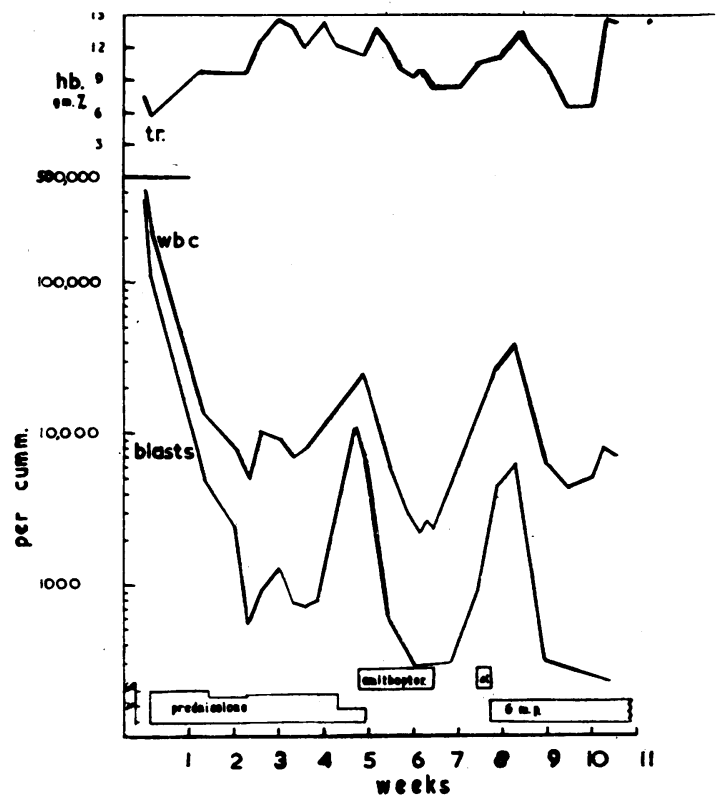

FIG. 2.-Acute leukaemia in a two-year-old child. The marrow was packed with undifferentiated primitive cells. Treatment with prednisolone resulted in a rapid remission. Amithopterin was substituted, but this was withdrawn following toxic effects, and after a second attempt, which was rapidly followed by toxic effects, a course of mercaptopurine was commenced. The patient obtained a good temporary remission.

appear to alter significantly the antibody titre in the maternal serum nor influence the haemolytic process in the infant. On the other hand, Hunter (1954) has suggested that as the disease may be associated with adrenal cortical involution in the newborn infant, cortisone administered to the mother during the course of pregnancy may result in reduction in stillbirth rate as well as in the mortality rate of the newborn infants who undergo exchange transfusions. ACTH therapy to the newborn infants immediately after birth in one series of cases resulted in reduction of antibody titre and temporary control of haemolysis (Geppert et al., 1953).

Steroids have proved effective in treatment of favism (Becker, 1954). No significant benefit has been obtained in paroxysmal nocturnal haemoglobinuria. Coleman and Finch (1956) showed that in hereditary spherocytosis large doses of cortisone increased the cell survival time, probably due to a non-specific effect of cortisone on splenic action.

\section{Leukaemia}

Early in the study of steroids their value in treatment of acute leukaemia was established (Farber et al., 1950). It is now realized that they are not the hoped-for panacea but they do fill an important place in the management of leukaemia.

\section{Acute Leukaemia}

Lymphoblastic Leukaemia. Maximal effect, often with dramatic improvement, is found in lymphoblastic leukaemia. Complete remissions have been reported in 82 per cent. of cases in children by Fessas et al. (1954) and equally favourable have been the findings of Wintrobe (1956). Adults, however, are relatively refractory to $\mathrm{ACTH}$ and cortisone (Hayhoe and Whitby, 1955). The M.R.C. Panel (1954) reported good remissions in 70 per cent. of children and in a smaller number of adults resistance to the antimetabolite begins to develop (Fig. 2).

In an adequate remission the leucocyte count falls to normal range in three to seven days with a decrease in the percentage of blasts. After the first week the platelets increase and after the second week the haemoglobin rises. At the end of four to six weeks the bone marrow is likely to be normal. The duration of the remission varies greatly from weeks to several months. After relapse, a second remission on steroids will be less complete or may not develop at all. Leucopenia is not an absolute contraindication to steroid therapy.

\section{Myeloblastic and Monoblastic Leukaemia}

In myeloblastic and monoblastic leukaemia steroids not only fail to produce remission but have been shown to accelerate the leukaemic process, often converting an aleukaemic phase into a frankly leukaemic process at an alarmingly rapid rate (Robson, 1954) (Fig. 3). Bjorkman (1956) has suggested that this might even be of use as a diagnostic test in differentiating cell types in acute leukaemia, but this is a somewhat drastic manoeuvre. Certainly, development of a frankly leukaemic picture should be an indication to take the patient off steroid therapy.

There have been scanty reports on the use of steroids in the rare condition of eosinophilic leukaemia. Davidson et al. (1952) found no beneficial result in a one-year-old infant, although previously Donohue et al. (1950) had found a good initial response in a seven-year-old boy, who had thirteen weeks' remission after the first two courses of treatment.

\section{Chronic Leukaemia}

In chronic lymphatic leukaemia cortisone gives temporary benefit which is less well sustained than that from X-ray therapy, but cortisone is of especial value in cases where there is a thrombocytopenia or an associated haemolytic anaemia. The 


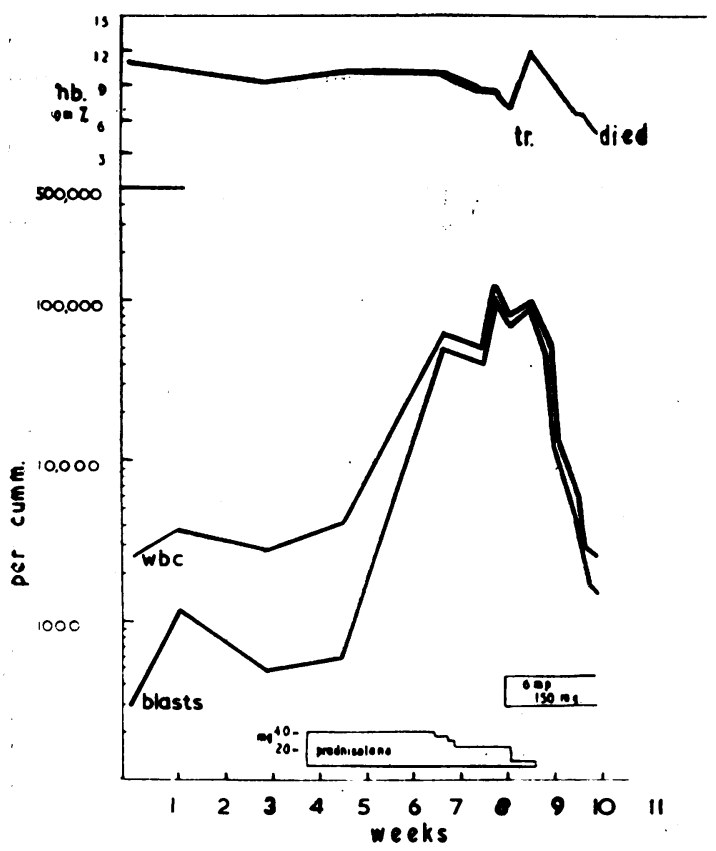

FIG. 3.-Acute leukaemia in a 77-year-old woman. On admission the bone marrow showed undifferentiated primitive cells. After cortisone therapy the peripheral blood became frankly leukaemic and the primitive cells differentiated into myeloblasts. There was rapid deterioration in the patient's condition, followed by death.

steroids in the treatment of these complications has been discussed above.

In chronic myeloid leukaemia steroid therapy does not produce remissions and may even accelerate the leukaemic process.

\section{Reticuloses}

Steroids are not the treatment of choice but may be of some value in Hodgkin's disease and in lymphosarcoma when there is an associated haemolytic anaemia. Alpert et al. (195I) reported that the undesirable side-effects of anorexia, nausea and vomiting as a result of nitrogen mustard, are minimized when the drug is combined with cortisone. Hochman and Ickowicz (1954) reported that in eleven cases of lymphoblastic disease (lymphosarcoma, retriculosarcoma and giant follicle lymphoma) and Hodgkin's disease, in which resistance had developed to nitrogen mustard, remissions of I to 4 months' duration followed when the nitrogen mustard was administered with small doses of cortisone. This may be partly explained by the suggestion that nitrogen mustard acts by stimulation of adrenal cortical secretion and that resistance develops because of an exhaustion of this secretion. Nabarro et al. (1955) found that prednisone alone in a dose of $30 \mathrm{mg}$. daily produced a satisfactory remission in a patient with Hodgkin's disease.

\section{Multiple Myeloma}

Thorn et al. (1950) reported that a patient im- $\frac{c}{c}$ proved as a result of treatment with ACTH.) Clinical improvement was associated with a fall $\stackrel{5}{?}$ in globulins and the disappearance of plasmablasts? from the bone marrow. Others have been less enthusiastic, though Adams et al. (1954) reported $\frac{}{\widetilde{D}}$

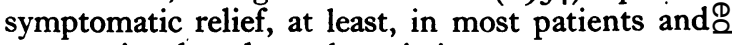
an occasional prolonged remission.

Volpé et al. (1956) reviewed the condition of essential cryoglobulinaemia. ACTH treatment ${ }_{-}^{\circ}$ resulted in clinical benefit in several cases but $\vec{\omega}$ only in some of them did the concentration of cryoglobulin fall parallel with the degree of clini-o cal improvement. However, Wirtschafter et al.$\underline{.}$ (1956) observed the association between the dis- $\rightarrow$ appearance of the cryoglobulin and clinical re-ci missions following treatment with cortisone $\mathrm{N}$ whereas the withdrawal of cortisone was im- $\omega$ mediately followed by the reappearance of the abnormal protein and clinical relapse.

In macroglobulinaemia steroids may produce a temporary remission but on the whole they have little effect either on the course of the disease or $\bar{\phi}$ on the abnormal protein present. (Mackay et $\vec{c}$ al., 1956; Laurin et al., 1957).

\section{Infectious Mononucleosis}

Prompt improvement of severe glandular fever, especially of the anginose type, has been reported following treatment with steroids $\mathbb{Q}$ (Mandel et al., 1955; Bender and Houghton, 1953; Brutsche and Naegele, 1954; Doran and $\frac{0}{3}$ Weisberger, 1953). In Mandel's patient intravenous ACTH brought about a rapid decrease in the signs and symptoms. Improvement was clinically obvious within sixteen hours and the 3 pharyngeal inflammation promptly subsided-i: before this a tracheotomy had been indicated. 3 . However, abnormal cells were present in the peripheral blood even after all the abnormal physical signs had disappeared. Steroids were reported to have been of dramatic value in cases of infectious mononucleosis complicated byo thrombocytopenia (Frenkel et al., 1956) or by meningoencephalitis (Copeman, 1956).

\section{Aplastic and Refractory Anaemias}

As mentioned previously, steroids stimulate erythropoiesis and this appears to be the basis for the slight improvement sometimes seen in cases of secondary hypoplastic anaemia as a result of $\stackrel{\oplus}{\rightleftharpoons}$ steroid therapy. However, little can be done to 0 stimulate an aplastic marrow into activity. In primary refractory anaemia steroid therapy has 
more frequently been followed by haematological improvement which is characterized by reticulocytosis in the blood, increased iron utilization and the conversion of a hypoplastic bone marrow to normal. Steroid therapy appears to be equally effective in cases where the anaemia is associated with a normal bone marrow (Loeb et al., 1953; Hill and Hunter, I95I).

\section{Agranulocytosis}

Rapid improvement has been noted in cases of agranulocytosis due to amidopyrine (Hart et al., 1952; Durant, et al., 1955), tapazole treatment of hyperthyroidism (Levine and Rosenberg, 1954), sulphadiazine (McMillan, I95I), propylthiouracil (Murray et al., 1957) and other factors (Caldwell et al., 1950; Virkkunen, 1953; M.R.C. Panel, 1953). However, it is difficult to assess the role of steroids in many of these cases, as often withdrawal of the offending drug will result in a natural remission.

\section{Hypersplenism}

In primary hypersplenism steroids have been shown to produce clinical benefit and haematological response with restoration to normal of the platelets and the neutrophil count (Bethell et al., 195I). There does not appear to be any correlation between the effect of steroid therapy and response to splenectomy.

In secondary hypersplenism steroids do not appear to have any beneficial effect on the blood disorder.

\section{Conclusion}

Table I indicates the blood disorders in which steroids are the treatment of choice or at least serve a purpose. Their effectiveness can be assessed only after adequate doses have been administered for an adequate length of time. In adults treatment should be commenced with a daily dose of 300 to $400 \mathrm{mg}$. of cortisone, or approximately one quarter the dose of prednisone or prednisolone or 200 units of ACTH. If benefit results this is shown within a fortnight. If one steroid has not been effective others should be used by various routes of administration before this form of therapy is discarded.

Steroids are no panacea but they are of definite value in certain blood diseases, especially when their use is integrated with other forms of treatment.

\section{Acknowledgment}

I wish to thank Professor J. V. Dacie for his invaluable advice in the preparation of this review.
TABLE I

Use of Steroids in Blood Disorders

\section{Maximum Value}

Acute idiopathic thrombocytopenia purpura.

Acquired (auto-immune) haemolytic anaemia (idiopathic or secondary).

Lymphoblastic leukaemia.

Severe infectious mononucleosis.

\section{Possible Value}

Chronic idiopathic thrombocytopenia purpura.

Henoch-Schonlein disease.

Favism.

Chronic lymphatic leukaemia.

Reticuloses (including Hodgkin's disease).

Multiple myelomatosis.

Refractory anaemia.

Hypoplastic anaemia.

Agranulocytosis.

Primary hypersplenism.

\section{Little or No Value}

Thrombotic thrombocytopenia purpura.

Congenital haemolytic anaemias.

Paroxysmal nocturnal haemoglobinuria.

Toxic haemolytic anaemias.

*Erythroblastosis foetalis.

*Secondary thrombocytopenia.

Secondary hypersplenism.

* Good effect has been reported in some cases.

\section{Probably contra-indicated}

Monoblastic leukaemia.

Myeloblastic leukaemia.

Chronic myeloid leukaemia.

\section{BIBLIOGRAPHY} ADAMS, W. S., MASON, E. D., and BASSETT, S. H. (1954),
f. clin. Invest., 33, I03.

ADELSON, E., HEITZMAN, E. J., and FENNESSEY, J. F. (1954), Arch. intern. Med., 94, 42.

ALPERT, L. K., ZIMMERMAN, H. J., and SCHERR, E. H. (1951), 'Proc. 2nd Clinical AC'TH Conf.,' p. 235, Churchill,
London.

BECKER, A. H. (1954), f. Amer. med. Ass., 155, 1158.

BENDER, C. E., and HOUGHTON, B. C. (1953), Northw. med. 52, 922.

BETHELL, F. H., MILLER, S., and MEYERS, M. C. (I95I), 'Proc. 2nd Clinical ACTH Conf.,' p. I73, Churchill, London.

BJORKMAN, S. E. (1956), Acta haemat. (Basel), 15, 175.

BRUTSCHE, R. L., and NAEGELE, C. F. (1954), Calif. Med., 80, 408 .

BURCHENAL, J. H., and ELLISON, R. R. (1956), 'Progress in Haematology; p. 265, Grune \& Stratton, New York.

CALDWELL, A. L., ADAMS, J. W., ANDERSON, J. F. C., and DICK, A. A. (1950), Canad. med. Ass. Ұ., 62, 506.

COHEN, A. S. (1957), Brit. med. $\mathcal{F}$., i, 143.

COLEMAN, D. H., and FINCH, C. A. (1956), f. Lab. clin. Med., 47,602 .

COPEMAN, H. A. (1956), Med. F. Aust., 2, 925.

COSGRIFF, S. W., DIEFENBACH, A. F., and VOGT, W. (1950), Amer. F. Med., 9, 752.

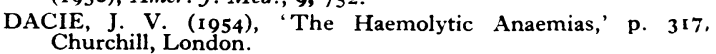

DAMESHEK, W. (1952), Brit. med. f., ii, 61 2

DAMESHEK, W., and KOMNINOS, Z. D. (1956), Blood, 11, 648. DAVIDSON, L. S. P., GIRDWOOD, R. H., and SWAN, H. T. (1952), Brit. med. Э., ii, 1059.

DE GRUCHY, G. C. (1954), Aust. Ann. Med., 3, 106.

DONOHUE, W. L., SNELLING, C. E., JACKSON, S. H., KEITH, J. D., CHUTE, A. L., LASK̇I, B., and SILVERTHORNE, N.'(1950), F. Amer. med. Ass., 143, 154.

DORAN, J. K., and WEISBERGER, A. S. (1953), Ann. intern. Med., 38, 1058 .

DOUĠHERTY, T. F., and WHITE, A. (r9+3), Science, 98, 367. 
DURAND, O. H., FLORY, C. M., and HALL, W. S. (1955), New Engl. F. Med., 252, 1038.

EISENMENGER, W. J., SLATER, R. J., and BONGIOVANNI, A. M. (1952), Amer. F. Med., 13, 27.

FARBER, S., SHWACHMAN, H., TOCH, R., DOWNING, V., KENNEDY, B. H., and HYDE, J. (1950), ' Proc. rst Clinical ACTH Conf.,' p. 328 , Churchill, London.

FESSAS, P., WINTROBE, M. M., THOMPSON, R. B., and CARTẄIGHT, G. E. (1954), Arch. intern. Med., 94, 384.

FRENKEL, E. P., SHIVER, C. B., BERG, P., and CARIS, T. N. (1956), $\mathfrak{f}$. Amer. med. Ass., 162, 885 .

GENDEL, B. R., YOUNG, J. M., and KRAUS, A. P. (1952), Amer. F. Med., 13, 3

GEPPERT, L. J., AKEROYD, J. H., and SIMPSON, J. W. (1953), Pediatrics, 12, 72.

HART, F. D., WRAITH, D. G., and MANSELL, E. J. B. (1952), Brit. med. F., i, 1273 .

HAYHOE, F. G., and WHITBY, L. (1955), Brit. F. Haemat., I, I.

HENCH, P. S., KENDALL, E. C., SLOCUMB, C. H., and POLLEY, H. F. (1949), Proc. Mayo Clin., 24, I8I.

HILL, J. M., and HUNTER, R. B. (r95I), 'Proc. 2nd Clinical ACTH Conf., p. 181 , Churchill, London.

HILLS, A. G., FORSHAM, P. H., and FINCH, C. A. (1948), Blood, 3, 755 .

HOCHMAN, A., and ICKOWICZ, M. (1954), Brit. F. Radiol., 27, 467.

HUNTER, O. B. (1954), F. Amer. med. Ass., 154, 905.

LAURIN, J. G., BEAUREGARD, J. M., and PROVOST, G. (1957), Canad. med. Ass. F., 76, 296.

LEVINE, B., and ROSENBERG, D. V. (1954), Ann. intern. Med., 41, 844 .

LOEB, V., MOORE, C. V., and DUBACH, R. (1953), Amer. 7 . Med., 15, 499.

MACKAY, I. R., ERIKSEN, N., MOTULSKY, A. G., and VOLWILER,' W. (1956), Ibid., 20, 564 .

MCMILlAN, J. S. (1951), Amer. F. med. Sci., 222, 392.

MANDEL, W., MARILLEY, R. J., and GAINES, L. M. (1955) f. Amer. med. Ass., 158, 1021.
MEACHAM, G. C ORBISON, J L, HEINLE, R. W., STEELE H. J., and SCHAEFER, J. A. (I95I), Blood, 6, 706.

MEYER, L. M., and RITZ, N. D. (1954), F. Amer. med. As尺

MOREY, D. A., WHITE, J. B., and DAILY, W. M. (1956 Arch. intern. Med., 98, 821 .

M.R.C. Panel on Haematological Application of ACTH and Cortisone, Preliminary Report (1952), Brit. med. $\mathcal{F}$., i, 1261 .

M.R.C. Panel on Haematological Application of ACTH ary Cortisone, and Report (1953), Ibid., ii, 1400.

M.R.C. Panel on Haematological Application of ACTH arf Cortisone, 3rd Report (1955), Ibid., ii, 455.

MURRAY, J. F., RABINER, S. F., and KABAKOW, B. (I957) Ann. intern. Med., 46, 387.

NABARRO, J. D. N., STEWART, J. S., and WALKER, (1955), Lancet, ii, 993.

ROBSON, H. N. (1954), Med. F. Aust., I, 516.

STEFANINI, M., and MARTINO, N. B. (1956), New Engl. Med., 254, 313 .

THOMPSON, M., SINCLAIR, R. J. G., and DUTHIE, J. J. $\dot{R}$ (1954), Brit. med. Э., i, 899.

THORN, G. W., FORSHAM, P. H., PRUNTY, F. T. G., an HILLS, A. G. (1948), 7. Amer. med. Ass., 137, 1005. خे

THORN, G. W., FORSHAM, P. H., FRAWLEY, T. F., HILIO S. R., ROCHE, M., STAEHELIN, D., and WILSON, D: (1950), New Engl. Y.' Med., 242, 824 .

VIRKKUNEN, M. (1952), Arch. intern. Med., 90, 580.

VOLPE, R. BRUCE-ROBERTSON, A., FLETCHER, A. A an CHARLES, W. B. (1956), Amer. $\mathcal{F}$. Med., 20, 533.

WALD, N., and KISSIN, M. (1955), F. Amer. med. Ass., 159, 20.

WINTROBE, M. M. (1956), 'Clinical Haematology,' p. $988 \mathrm{O}$ Kimpton, London.

WINTROBE, M. M., CARTWRIGHT, G. E., PALMER, J. GO KUHNS, W. J., and SAMUELS, L. T. (I95I), Arch. intern? Med., 88, 310.

WIRTSCHAFTER, $Z$. T., GAULDEN, E. C., and WILLIAM. D. W. (1956), Arch. Derm. Syph. (Chicago), 74, 302.

Bibliography continued from page 334-S. C. Truelove, M.A., M.D.(Camb.), M.R.C.P.

EVANS, A. S. SPRING, H., and NELSON, R. S. (1953), Ann. intern. Med., 38, I I I 5 , I 134 , and 1148 .

FINLAY, I. M., and WIGHTMAN, K. J. R. (1956), Ibid., 45, 191. GRAY, S. J., BENSON, J. A., REIFENSTEIN, R. W., and SPIRO, H. M. (1951), Ұ. Amer. med. Ass., 147, 1529 .

HIRSCHOWITZ, B. I., STREETEN, D. H. P., POLLARD, H. M., and BOLDT, H. A. (r955), Ibid., 158, 27.

HUBER, T. E., and WILEY, A. T. (1955), Ann. intern. Med., 42, IOI I.

HUNTER, R. C., and WARD, J. R. (1957), Amer. F. dig. Dis., New Series, 2, 388.

KIRSNER, J. B., PALMER, W. L., and KLOTZ, A. P. (1952), Gastroeneterology, 20, 229 .

MACKAY, I. R., TAFT, L. I., and COWLING, D. C. (1956), Lancet, ii, 1323.

MACHELlA, T. E., and HOLLAN, O. R. (I95I), Amer. F. med. Sci., 221, 501 .

MARCHAND, P. (1955), S. Afr. med. F., 29, 195

RICE-OXLEY, J. M., and TRUELOVE, S. C. (1950), Lancet, i, 663.

ROGERS, N. C., WILSON, A. O., MEYNELL, M. J., and COOKE, W. 'T. (1956), Ibid., 2, 6'51.

SANDWEISS, D. J. (1954), Gastroenterology, 27, 604.

SBOROV, V. M., GIGES, B., PLOUGH, I. C., and MANDEL, W. (1954), $\mathscr{F}$. Lab. clin. Med., 43, 48.

SHERLOCK, S., SUMMERSKILL, W. H. J., and DAWSON, A. M. (1956), Lancet, ii, 689 .
SHERLOCK, S. (1957), Amer. 7. dig. Dis., New Series, 2, 353. SKLAR, M., KIRSNER, J. B., and PALMER, W. L. (1957) Ann. intern. Med., 46, I.

SOCIETÉ DE GASTRO-ENTÉROLOGIE DE LA REGIONं LYONNAISE (1956), Arch. Mal. Appar. dig., 46, 214, et seq SPELLBURG, M. A. (1957), Gastroenterology, 32, 616.

STEIN, A. A., and WRIGHT, A. W. (1956), f. Amer. med. Ass. 오 16I, 508 .

STEPHENSON, H. E., JR., PFEFFER, R. B., and SAYPOI G. M. (1952), Arch. Surg., 65, 307.

TRUELOVE, S. C. (1956), Brit. med. F., ii, 1267.

TRUELOVE, S. C. (1957), Ibid., i, 1437.

TRUELOVE, S. C., and WITTS, L. J. (I954), Ibid., ii, 375.

TRUELOVE, S. C., and WITTS, L. J. (1955), Ibid., ii, 104I.

TULIN, M., KERN, F., JR., and ALMY, T. P. (1952), J. AmerG med. Ass., 150, 559

WANG, C. I., JANOWITZ, H. D., and ADLERSBERG, D. (1956) Gastroenterology, 30, 475 .

WHEELOCK, F. C., and WARREN, R. (1955), New Engl. F. Med. 252, 421 .

WINKLER, K., and TYGSTRUP, N. (1957), Acta med. scand.) I57, 149 .

WIRTS, C. W., and REHFUSS, M. E. (1956), Gastroenteralogia (Basel), 86, 689.

ZETZEL, L. (1956), New Engl. F. Med., 254, 990, and roz9.

.

